\title{
Penerapan Pemasaran Daring berbasis Media Sosial dalam Rangka Pemberdayaan Pedagang Burung Pasar Depok Surakarta
}

\author{
Irwan Christanto Edy ${ }^{1)}$, Shandy Marsono ${ }^{2)}$, Heriyanta Budi Utama ${ }^{3)}$ \\ ${ }^{1.3}$ Dosen Manajemen, ${ }^{2}$ Dosen Akuntansi, STIE Adi Unggul Bhirawa, Surakarta \\ Email: irwan aub@yahoo.co.id
}

\begin{abstract}
Abstrak
Pasar Depok dikenal dengan Pasar Burung di Kota Surakarta. Pasar Depok merupakan pasar tradisional yang terkenal dengan pasar satwa seperti burung dan mamalia, namun yang paling dominan berupa burung. Beberapa permasalahan manajemen muncul di pasar Depok pemasaran produk, manajemen usaha. Banyak pedagang yang mengelola usahanya tanpa memiliki dasar pengetahuan maupun ketrampilan perihal manajemen pemasaran terutama yang menyangkut pemasaran berbasis internet atau daring. Rata rata pedagang hanya menjalankan usaha dengan mengandalkan naluri/insting dan pengalaman saja. Penggunaan teknologi masih kurang diperhatikan oleh para pedagang. Berdasarkan kajian situasi tim pengabdi pada masyarakat menyelenggarakan kegiatan pelatihan pemasaran daring khususnya dalam memasarkan produk berbasis media sosial. Materi pengabdian ini diberikan dengan tujuan untuk menumbuhkan jiwa pemasaran yang tangguh dan mandiri serta mengoptimalkan teknologi berbasis media sosial. Luaran dari kegiatan pengabdian pada masyarakat ini adalah para pedagang 1)memiliki pengetahuan, motivasi dan pemahaman tentang strategi pemasaran daring, 2)memiliki ketrampilan menggunakan teknologi dan media sosial untuk memasarkan produk, 3) memiliki kemampuan untuk memasarkan produk dengan menggunakan teknologi dan media sosial. Dampak akhir dari kegiatan pengabdian ini para pedagang mampu meningkatkan pemasaran produk dan meningkatkan pendapatan dan kesejahteraan hidup. Kendala dalam kegiatan pengabdian ini antara lain yaitu 1) karena masih dalam suasana pandemi Covid-19 maka komunikasi dilakukan secara virtual dan komunikasi langsung antara tim dengan pedagang dibatasi dengan protokol kesehatan yang ketat, 2) keterbatasan waktu, 3) keterbatasan biaya, karena banyak pedagang yang mengeluhkan masalah kuota internet. Namun, meski ada keterbatsan, kegiatan dapat dilaksanakan dengan baik.
\end{abstract}

Kata kunci : Pemberdayaan pedagang, pemasaran daring, media sosial

\section{PENDAHULUAN}

Pasar Depok Merupakan pasar tradisional yang terkenal dengan pasar satwa seperti burung dan mamalia, namun yang paling dominan berupa burung. Terdapat berbagai jenis burung dan berbagai peralatan untuk memelihara burung seperti sangkar dan pakan burung. Luas area pasar cukup besar yaitu $12.754 \mathrm{~m}^{2}$. Pengelola pasar yaitu pihak Dinas Pengelola Pasar (DPP) Kota Surakarta bekerjasama dengan paguyuban IKPBS (Ikatan Pedagang Burung Surakarta). Paguyuban berfungsi sebagai mediator antara pedagang dengan pihak pengelola, menyampaikan aspirasi dan permasalahan-permasalahan pedagang.

Pedagang Umumnya berasal dari wilayah Subosukowanasraten, namun yang paling banyak adalah orang Solo, Karanganyar, dan Sukoharjo. Asal Komoditas berasal dari luar kota bahkan luar pulau Jawa seperti dari Sumatera, Sumbawa, NTT, Kalimantan, Lampung. Pasar Depok juga ada lahan parkir dan tempat bongkar muat barang sehingga kendaraan bisa masuk area pasar dan tidak menganggu atau parkir di pinggir jalan.Kicauan aneka burung dan kokok ayam memberi suasana pagi yang cerah di kawasan pasar burung Depok Surakarta. Para penghobi burung lalu lalang mencari burung yang disukainya. Sebagian sekedar cuci mata untuk menyegarkan suasana di tengah pandemi pandemi yang tak berkesudahan.

Pandemi Covid-19 telah menyebar di seluruh dunia yang mana banyak negara terserang penyakit ini sampai menghadapi tingkat kematian dan kerugian ekonomi yang cukup tinggi. Pandemi Covid-19 menyebabkan peningkatan angka pengangguran. Pandemi Covid-19 memberikan dampak yang signifikan terhadap perekonomian masyarakat. Banyak masyarakat yang mengeluh dan terhenti aktivitasnya karena pandemi Covid-19.

Di tengah kesulitan ekonomi akibat pandemi, para pedagang di pasar burung Depok Surakarta mencoba bertahan. Mereka melakukan apa saja agar dagangannya tetap terjual. Tentunya dengan menerapkan protokol kesehatan yang ketat. Wasjiyanto yang akrab dipanggil Ajek Kenari, salah seorang 
pedagang burung Kenari Pasar Depok mengungkapkan pandemi covid-19 bukan berarti membuat pedagang tidak dapat berkreativitas, tetapi justru dimasa pandemi ini harus dapat menyesuaikan diri untuk bertahan hidup, tetap dapat menghasilkan uang.

Strategi pemasaran masih mengandalkan strategi konvensional yang pemasaran dari mulut ke mulut atau getok tular. Selama ini yang terjadi hampir sebagian besar pedagang tidak pernah menyusun dan pencatatan pemasaran produk secara cermat dan tertib. Berdasarkan kajian situasi itu maka tim pengabdi menyelenggarakan kegiatan penyuluhan dan pelatihan pemasaran daring berbasis media sosial dengan system dropship.

Permasalahan non fisik pada pasar tradisional termasuk pasar Depok ini terkait dengan masih rendahnya pengetahuan dan ketrampilan (softskill) terutama terkait dengan stratetgi pemasaran bisnis yang menyangkut pemasaran. Oleh karena itu, program pengabdian masyarakat ini dilaksanakan dalam rangka mengatasi permasalahan tersebut dengan memberikan pengetahuan dan ketrampilan khususnya bidang pemasaran yang berbasis teknologi informasi. Dalam pengelolaan keuangan tersebut yang menjadi fokus adalah pemahaman tentang intrumen pemasaran berbasis teknologi informasi seperti Facebook, Instagram, Twiters. Pedagang diharapkan memiliki pengetahuan dan ketrampilan (softskill) untuk mengelola pemasaran daring dengan media social sistem dropship yang akan meningkatkan volume penjualan

\section{Kajian Literatur}

Kinerja pemasaran juga dikatakan sebagai kemampuan organisasi untuk mentransformasikan diri dalam menghadapi tantangan dari lingkungan baik eksternal maupun internal dengan perspektif jangka panjang (Keats et.al, 1998). Lingkungan eksternal memang telah menjadi bagian penting dari perusahaan dan merupakan hal yang sulit untuk dikendalikan oleh setiap perusahaan. Perusahaan hanya dapat mengenalinya untuk kemudian mengelola dengan baik sehingga dapat memberi manfaat bagi perusahaan. Perubahan lingkungan eksternal baik lingkungan makro maupun industri akan memiliki dampak terhadap kinerja perusahaan, khusus dinamika perkembangan teknologi informasi seperti internet menuntut setiap perusahaan untuk melakukan penyesuaian dalam membnagun strategi bisnis

Teknologi Internet memiliki peran yang ganda, artinya internet sebagai teknologi dapat berlaku sebagai faktor lingkungan makro yang mempengaruhi kinerja perusahaan, tetapi teknologi internet juga dapat menjadi sumber daya (market resource), yang digunakan untuk meningkatkan kinerja pemasaran dan berdampak pada prospek perusahaan. Teknologi sebagai faktor lingkungan makro mengalami perkembangan yang sangat pesat. Perkembangan penggunan internet di Indonesia sangat cepat. Data dari internetworldstats.com (2014) menunjukan bahwa jumlah pengguna internet di Indonesia saat ini sekitar 71.190.000 yang tersebar di 34 propinsi di Indonesia.

Dalam situs tersebut disebutkan bahwa Indonesia menempati peringkat ke empat sebagai pengguna internet terbesar di kawasan asia. Data tersebut, menggambarkan bahwa masyarakat Indonesia sudah mengenal dan sadar akan internet. Asosiasi Penyelenggara Jasa Internet Indonesia (APJII) mempublikasikan data bahwa media akses pengguna internet di dominasi oleh smartphone $96,6 \%$, telepon kabel 85\%, Jaringan nirkabel (WI-FI) 49\% dan sisanya TV Kabel dan satelit masing masing sebesar 11,4\% dan 3,4\% (APJII, 2012).

Dari sumber data tersebut dikatakan bahwa mayoritas intensitas akses internet adalah media sosial 87,8\%, pencarian informasi (browsing) 68,9\% dan perdagangan online 0,1\%. Data Kementrian Komunikasi dan Informatika juga mengungkapkan bahwa pengguna internet tahun 2014 di Indonesia mencapai 82 juta orang dan Indonesia menduduki peringkat ke-4 terbesar di dunia dalam pemakaian sosial media yaitu Facebook. Data tersebut mengungkapkan bahwa pengaruh internet di Indonesia sudah berkembang pesat jika dilihat dari pengguna.

Korelasi pengaruh internet dalam bisnis menunjukan hubungan yang kuat. Beberapa bisnis telah mulai terkena dampak yang langsung dari teknologi internet. Bisnis angkutan (tranportasi) merupakan salah satu sektor bisnis yang terkena dampak langsung dari perkembangan teknologi internet, khususnya munculnya aplikasi mobile seperti Go-jek, Uber dan Grab Car. Bidang telekomunikasi, kalangan operator telekomunikasi mengalami penurunan bisnis voice dan sms, setelah muncul WhatsApps (WA) dan Line, banyak pengguna SMS yang beralih ke WA dan Line. Bisnis media cetak, surat kabar dan buku termasuk yang terganggu berat dengan kehadiran media sosial seperti Facebook dan instagram, serta munculnya blog blog.

Bisnis televisi, juga sudah tersaingi dengan keberadaan Youtube dan sejumlah video streaming. Bisnis biro perjalanan (travel) konvensional sudah tergerus oleh kehadiran penyedia layanan reservasi 
online dan online ticketing seperti traveloka dan tiket.com. Demikian pula bisnis perbankan akan digerogoti juga oleh sejumlah pemain berbasis aplikasi financial technology (Fintech). Sarjono (2016) CTO IBM Indonesia, menyatakan bahwa perkembangan teknologi internet dan daring dengan sistem dropship membuat pasar dan dunia bisnis bergejolak dan jika perusahaan tidak mendorong perubahan internal, maka perusahaan tidak akan marketable di mata pelanggan.

\section{METODE PENGABDIAN}

Dalam penyelesaian permasalahan yang ada, maka tim pelaksana pengabdian pada masyarakat STIE-AUB Surakarta mengadakan kegitan dalam bentuk pemberdayaan yang mencakup memberikan pelatihan ketrampilan pengelolaan pemasaran daring dengan sistem dropship. Adapun materi penyuluhan yang akan diberikan kepada para pedagang Pasar Depok Surakarta adalah :

a. Ceramah tentang strategi pemasaran

b. Pelatihan membuat Facebook dan Instagram,

c. Praktek pemasaran dengan smartphone untuk membuat Facebook dan Instagram.

Dalam kegiatan pengabdian pada masyarakat ini, alur kegiatan yang digunakan mengacu pada kerangka pemecahan masalah sebagai berikut :

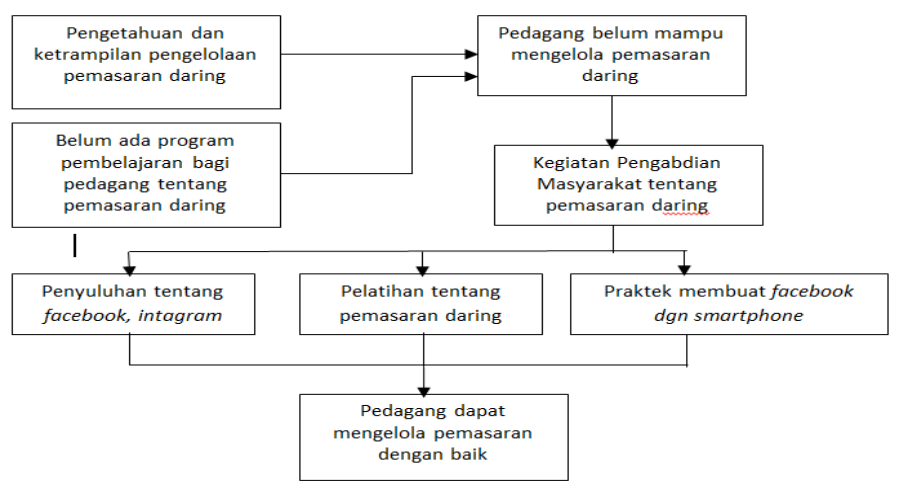

Gambar 1. Kerangka Pemecahan masalah

Dengan mengutamakan protokol kesehatan (prokes) karena masih dalam suasana pandemic Covid19 maka bentuk penyuluhan dan pelatihan dilakukan dengan komunikasi yang terbatas, dimana tim pengabdi melakukan komunikasi perorangan dengan didukung perangkat seperti makalah, masker, handphone dan alat tulis. Dengan bentuk kegiatan tersebut, tim pengabdi hanya mampu mengumpulkan peserta kegiatan dalam jumlah yang terbatas. Namun, kegiatan ini cukup menambah wacana pengetahuan pedagang dalam memasarkan produknya.

\section{HASIL DAN PEMBAHASAN}

Kegiatan Pengabdian pada Masyarakat kepada pedagang burung di pasar Depok ini telah memberikan manfaat sebagai berikut :

a. Pedagang akan mendapatkan pengetahuan dan ketrampilan dalam pengelolaan pemasaran daring dengan sistem dropship. Pengetahuan merupakan aspek yang penting untuk membentuk perilaku seseorang. Dengan pengetahuan pemasaran daring dengan mengoptimalkan media sosial pedagang akan mampu melakukan inovasi pemasaran, sehingga kinerja pemasaran akan meningkat. Dengan memberikan ketrampilan maka akan memberikan manfaat bagi pedagang :

1) sbg suatu sistem pembelajaran sebelum nantinya akan memulai kinerja yg sebenarnya.

2) mendapatkan banyak ilmu pengetahuan disetiap pembelajaran.

3) bisa mengetahui sampai dimana batas kemampuan.

4) menjadikan pedagang lebih kreatif dan inovatif dalam bekerja.

b. Pedagang akan mendapatkan pengetahuan tentang pentingnya Facebook dan Instagram. Teknologi dalam pemasaran mempunyai peran penting untuk meningkatkan eksistensi sebuah perusahaan atau 
usaha. Peranan teknologi dalam pemasaran yakni menunjang kegiatan-kegiatan yang saling berhubungan sehingga pemasaran barang dan jasa dapat berjalan secara maksimal.

c. Tim pelakasana PKM, dapat memberikan kebahagian batin karena dapat memberikan ilmu kepada sesama. Hasil kegiatan pengabdian ini adalah

1) Adanya peningkatan kemampuan pedagang dalam mengelola pemasaran daring dengan sistem dropship untuk meningkatkan volume penjualan,

2) Pedagang memiliki kemampuan dan ketrampilan untuk pemasaran daring dengan sistem dropship,

3) Pemasaran daring dengan sistem dropship lewat Facebook dan Instagram.

Keberhasilan kegiatan pengabdian pada masyarakat dapat dilakukan dengan mengukur tingkat efektifitas dengan melakukan evaluasi hasil penyuluhan dan pelatihan. Pada proses evaluasi ini dapat dijadikan sebagai tolak ukur keberhasilan program pelatihan. Saat menjalani training memang diperlukan proses evaluasi untuk mengetahui seberapa besar perubahan yang dilakukan peserta apakah sudah memenuhi kriteria atau belum. Evaluasi pelatihan lebih fokus unuk meninjau proses pelatihan yang telah dilakukan. Dengan memanfaatkan data-data dan informasi selama proses training dapat mengukur tingkat pengetahuan dan ketrampilan peserta. Dengan begitu akan terlihat peserta mana yang benar-benar memiliki kompetensi yang baik.

a. Bentuk evaluasi yang dilakukan dengan pengamatan, pengawasan dan wawancara tentang materi yang diberikan dalam penyuluhan dan praktek. Hasil pengamatan menunjukan adanya peningkatan pengetahuan dan ketrampilan para pedagang.

b. Kriteria evaluasi adalah menjadi keberhasilan dari sasaran kegiatan khususnya pemahaman materi yang disampaikan dalam kegiatan. Evaluasi pemahaman materi dilakukan dengan metode Tanya jawab. Kelebihan metode tanya jawab adalah 1)akan dapat membangkitkan minat dan rasa ingin tahu peserta terhadap pokok bahasan yang akan dibahas, 2) Dapat memusatkan perhatian peserta pelatihan terhadap pokok bahasan, 3)dapat mengembangkan keaktifan belajar dan berpikir peserta.

Secara umum, langkah-langkah yang ditekan pada kegiatan pengabdian ini adalah pemanfaatan facebook dan instagram sebagai salah satu media sosial dalam pemasaran :

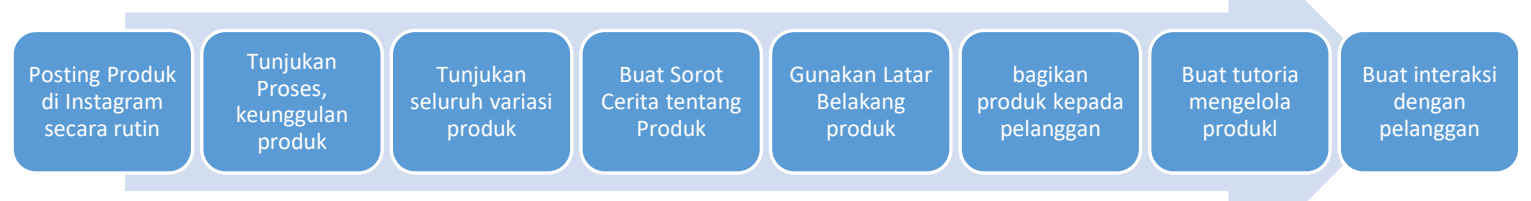

Gambar 2. Langkah-langkah Pemasaran berbasis Media Sosial
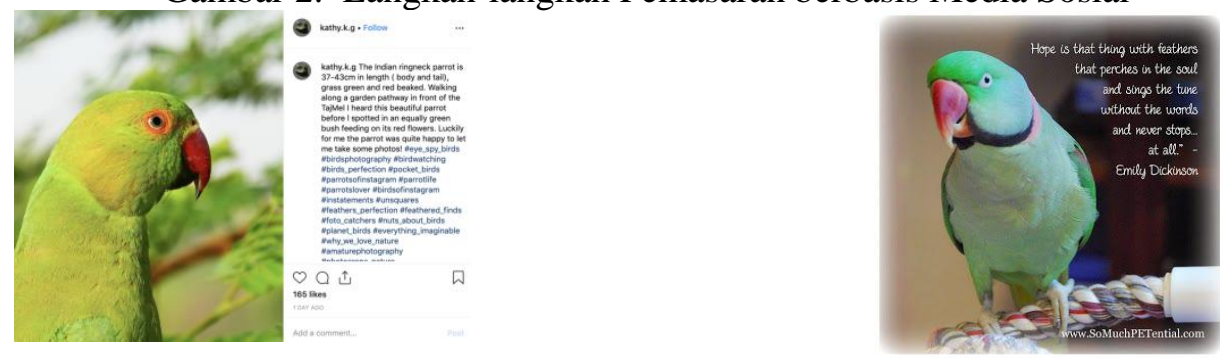

Gambar 3. Postingan Pemasaran Burung di Media Sosial

\section{SIMPULAN} adalah :

Hasil dari kegiatan pengabdian pada masyarakat untuk pedagang di Pasar Depok Surakarta ini

a. Peningkatan pengetahuan dan ketrampilan pedagang dalam mengelola pemasaran sehingga volume penjualan dapat meningkat. 
b. Memberikan edukasi terhadap pedagang tentang pengelolaan pemasaran daring dengan sistem dropship

c. Peningkatan ketrampilan tentang penggunaan Facebook dan Instagram untuk pemasaran daring dengan sistem dropship

\section{SARAN}

Tidak lanjut dari kegiatan pengabdian pada masyarakat untuk pedagang di Pasar Depok Surakarta ini adalah melakukan pelatihan tentang menajemen usaha.

\section{DAFTAR PUSTAKA}

Keats BW and Hitt MA. 1998. A Causal Model of Linkages Among Environmental Dimensions. Macro Organozational Characteristic and Performance". Academy of Management Journal. Vol. 31, p. 570598.

https://peluangusaha.kontan.co.id/news/berburu-burung-murah-di-solo

https://dinasperdagangan.surakarta.go.id/revitalisasi-pasar-tradisional/

https://blog.porinto.com/tips-menjual-produk-dropship/

https://www.domainesia.com/berita/daring-marketing-adalah-pemasaran-masa-kini/

https://www.harmony.co.id/blog/pemasaran-daring-membantu-peningkatan-penjualan-bisnis 